\title{
Development of a Novel Environmental Cell for In-Situ Gas Reaction Experiments via Aberration-Corrected STEM Imaging
}

\author{
L. F. Allard,* W. C. Bigelow, ${ }^{* *}$ S. H. Overbury, ${ }^{*}$ D. P. Nackashi*** and J. Damiano*** \\ *Physical Sciences Directorate, Oak Ridge National Laboratory, Oak Ridge, TN 37831 \\ **Department of Materials Science \& Engineering, University of Michigan, Ann Arbor, MI 48104 \\ ***Protochips, Inc., 617 Hutton Street, Suite 111, Raleigh, NC 27606
}

A novel heating technology composed of a disposable MEMS-based (microelectromechanical systems) device has recently been developed and shown to provide unique in-situ heating capabilities in electron microscopes [1]. Protochips, Inc. (Raleigh, NC) provides the Aduro ${ }^{\mathrm{TM}}$ heater technology, composed of a disposable MEMS device that serves both as the heating element and the specimen support grid, a TEM holder with electrical feed-throughs, and an external current source. This system has been shown to provide near instantaneous $\left(10^{6}{ }^{\circ} \mathrm{C} / \mathrm{s}\right)$ heating and cooling, and is stable to the limit of the microscope's specimen stage so full sub-Ångström image resolution in highangle annular dark-field imaging mode can be achieved on our JEOL 2200FS scanning transmission electron microscope (STEM/TEM) instrument, fitted with a hexapole corrector on the probe-forming lenses (CEOS GmbH, Heidelberg, Ger.). This heating technology is being extended to function in a closed cell system that allows heating in a gaseous environment for in-situ elevated temperature reaction studies. The design concepts and early results of testing of the environmental cell (E-cell) performance are detailed here.

The E-cell concept implies a closed cell assembly to contain the reaction gas, which is provided to the cell via supply and return tubes through the specimen rod. The gas is sealed within the cell by electron-transparent, amorphous silicon nitride windows, thru which the electron beam passes prior to and after interacting with the sample material. In the current design, the upper "window" of the cell is actually a standard Aduro ${ }^{\mathrm{TM}}$ heater chip, with a grid of holes in the heater membrane that are coated with an amorphous film of carbon or silicon nitride $\sim 25 \mathrm{~nm}$ thick. Figure 1 shows a general schematic of the center section of the cell. The heater window is fixed into a removable plate so that sample material (e.g. catalyst powder) can be deposited, and the plate is then sealed against a replaceable bottom window, also fixed in a removable plate. Figure 2 shows a top view of the E-cell holder designed to fit into the narrow URP (2mm) pole-piece gap of the JEOL 2200FS instrument.

We investigated the nature of high-resolution imaging with the beam passing first through a $25 \mathrm{~nm}$ amorphous $\mathrm{SiN}$ window. Figure 3 a shows in profile a gold nanoparticle on a FeOx support particle $(\mathrm{Au} / \mathrm{FeOx})$, in high-angle annular dark-field (HA-ADF) STEM imaging mode, and Fig. 3b shows another area with a perfectly oriented gold particle and individual $\mathrm{Au}$ atoms resolved, all after the beam has passed through the SiN window. A carbon film of similar thickness should be an even more ideal window material because of its lower atomic number. Figures $4 \mathrm{a}-4 \mathrm{c}$ show images of the same $\mathrm{Au} / \mathrm{FeOx}$ material imaged with the E-cell in full geometry, using a carbon film as the upper window over the heater chip. The cell was run at 2 Torr, and the images recorded with the catalyst heated to a nominal $500^{\circ} \mathrm{C}$ (temperatures of $>1000^{\circ} \mathrm{C}$ are possible with the Aduro ${ }^{\mathrm{TM}}$ heater chips). These results offer great promise as a route to in-situ studies of catalyst reactions at the highest resolutions possible, with ultimate control over heating and cooling rates [2]. 


\section{References}

[1] L.F. Allard, et al., Microscopy Research \& Technique (2003), 72(3): 208-215

[2] This research at the ORNL's High Temperature Materials Laboratory was sponsored by the U. S. DOE, Office of Energy Efficiency \& Renewable Energy, Vehicle Technologies Program.
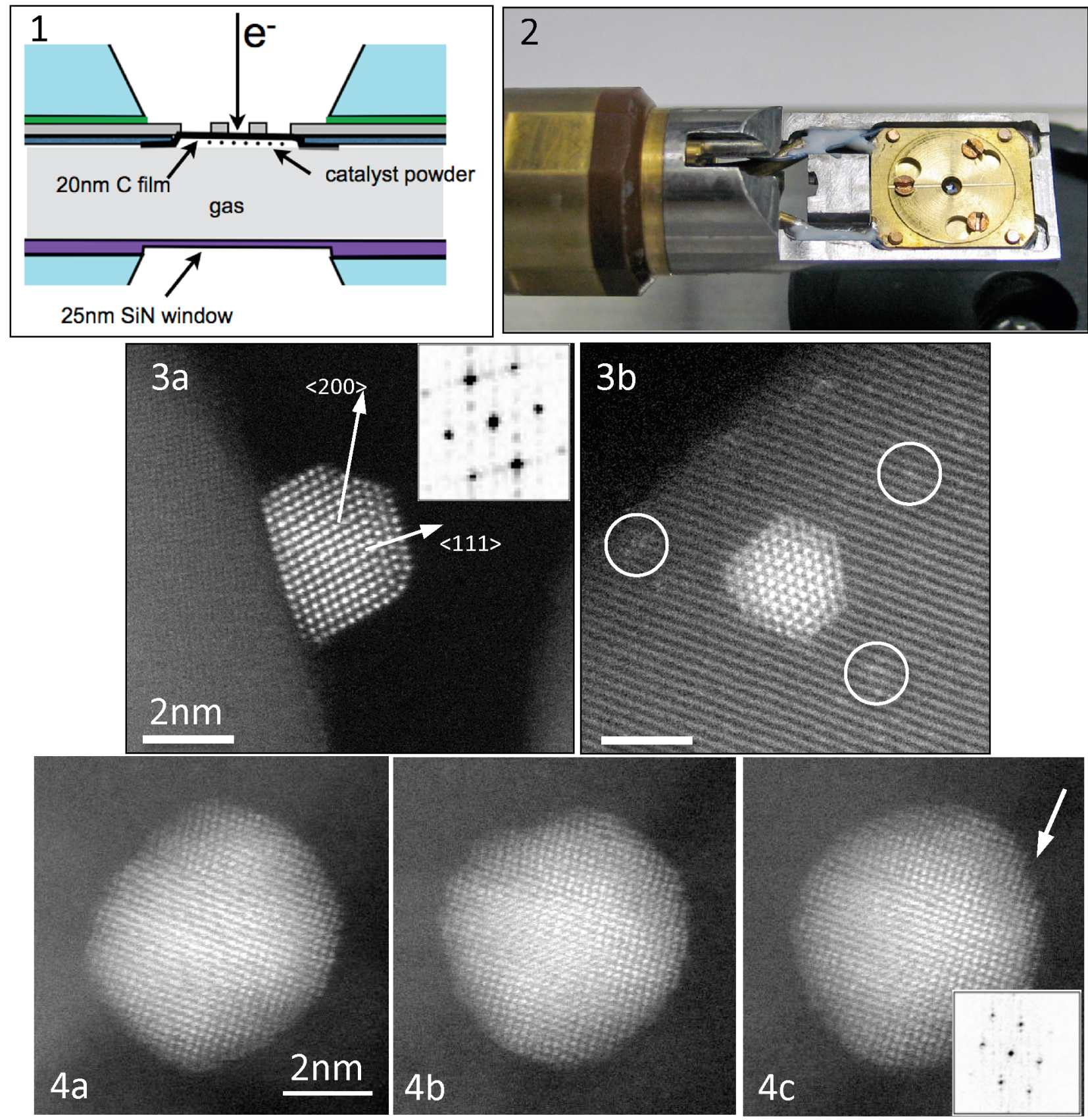

FIG. 1. Schematic of E-cell geometry, showing heater membrane upper window coated with a $\mathrm{C}$ film, with catalyst deposited on $\mathrm{C}$ film.

FIG. 2. View of E-cell prototype, designed for JEOL 2200FS STEM/TEM.

FIG. 3. a) $<110>$ Au nanoparticle in profile on FeOx support, imaged through $25 \mathrm{~nm} \mathrm{SiN}$ window; b) another $\mathrm{Au}$ particle on $\mathrm{FeOx}$, with single $\mathrm{Au}$ atoms also resolved (circles).

FIG. 4. Three frames from image sequence of $\mathrm{Au}$ nanoparticle with E-cell operating at $2 \mathrm{Torr}, 500^{\circ} \mathrm{C}$; particle imaged through a $25 \mathrm{~nm} \mathrm{C}$ window. Particle orientation is near $<100>$. Note $\{100\}$ ledges developed in $4 \mathrm{c}$ (arrow) as a result of heating. 